\title{
Spiritual Help for Persons Suffering from Depression
}

Ivan Platovnjak*

ivan.platovnjak@teof.uni-lj.si

https://orcid.org/0000-0001-7779-0889 https://doi.org/10.31192/np.18.2.3

UDK / UDC: 616.89-008.454:27-46

159.913:27-46

Izvorni znanstveni rad / Original scientific paper

Primljeno / Received: 14. siječnja 2020. / Jan 14, 2020

Prihvaćeno / Accepted: 7. svibnja 2020. / May 7, 2020

Currently, many experts are discussing and examining the impact of spirituality on health. It is no longer arguable to claim that spirituality has a positive effect on a person's health. Pope Francis highlights that, in the Catholic Church, every person finds a spirituality that can provide healing. The focus of this paper is limited to the impact of spirituality on the health of persons suffering from depression, particularly on the forms of spiritual help found in Christian spirituality. This paper will be presented in three chapters. In the first, the symptoms and causes of depression are examined. In the second chapter, the author explains what constitutes spiritual help for depressed persons and which aspects should receive special attention in order not to do more harm than good. Various forms of spiritual help for depressed persons within Christian spirituality are described in the final chapter.

Key words: Depression, Persons Suffering from Depression, Christian Spirituality, Health, Spiritual Help, discernment.

\footnotetext{
* Ivan Platovnjak, PhD, Assis. Prof., University of Ljubljana, Faculty of Theology; Address: Poljanska cesta 4, SI-1000 Ljubljana, Slovenia.
} 


\section{Introduction}

Today, depression is the most common mental health disorder. Some call it the epidemic of modern times. ${ }^{1}$ Many people seek healing in spirituality. ${ }^{2}$ Such a search for healing was confirmed as meaningful by the Pope Francis who highlights that it is just that, in the Catholic Church, every person finds a spirituality that can provide healing. ${ }^{3}$ The focus in this paper is confined to the impact of spirituality on the health of persons suffering from depression. Firstly, the symptoms and causes of depression are examined. Later, the author explains what constitutes spiritual help for depressed persons and which aspects should receive special attention in order not to do more harm than good by providing such spiritual help. In the final chapter, the various forms of spiritual help for the depressed persons within Christian spirituality are described.

\section{Persons Showing Symptoms of Depression}

Depression is one of the most prevalent mental health disorders in in the world. It entails much more than a mere feeling of sadness. It is an illness that affects the physical and mental well-being of a person as a whole. Not only does depression cause disorders of mood and reasoning, it also affects the functioning of the body and spirit as evidenced in the person's daily activities. As emphasized by Tim Clinton, depression is a mental state characterized by a pessimistic feeling of inadequacy accompanied by the inactivity that corresponds to this feeling. ${ }^{4}$

Depressive disorders exist on a spectrum of both type and severity. The Diagnostic and Statistical Manual of Mental Disorders (DSM-5) includes the following: major depressive disorder, persistent depressive disorder (dysthymia), substance/medication-induced depressive disorder, depressive disorder due to another medical condition, disruptive mood dysregulation disorder, premenstrual dysphoric disorder, and depressive disorder not otherwise specified. The common shared feature is »the presence of sad, empty, or irritable mood,

${ }^{1}$ Cf. WORLD HEALTH ORGANIZATION 2017, Depression and Other Common Mental Disorders. Global Helalth Estimates, https://apps.who.int/iris/bitstream/handle/10665/254610/ WHO-MSD-MER-2017.2-eng.pdf (12.05.2020), 6-9.

${ }^{2}$ Cf. Bojana FILEJ, Boris Miha KAUČIČ, Vpliv duhovnosti na kakovost življenja starejših v domačem in v institucionalnem okolju [The Influence of Spirituality on the Quality of Life of the Elderly in the Domestic and Institutional Environment], Bogoslovni vestnik, 79 (2019) 2, 555-568, 557-558, doi: https://doi.org/10.34291/BV2019/02/Filej.

${ }^{3}$ Cf. Pope FRANCIS, Apostolic Exhortation Evangelii Gaudium, (24.11.2013), http://w2.vatican.

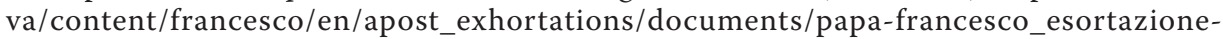
ap_20131124_evangelii-gaudium.html (18.11.2019), 89.

${ }^{4}$ Cf. Tim CLINTON, Ron HAWKINS, The Quick-Reference Guide to Biblical Counseling. Personal and Emotional Issues, Michigan, Baker Books, Kindle Edition, 2009, 72. 
accompanied by somatic and cognitive changes that significantly affect the individual's capacity to function.$^{5}$ The various syndromes are differentiated by factors of duration, timing, or presumed etiology.

Major depressive disorder represents the classic condition in this group. It is characterized by discrete episodes involving multiple clear-cut changes in affect, cognition, and neurovegetative functions. It is important to differentiate normal sadness or grief from a major depressive episode. While bereavement may cause great suffering it does not typically precipitate an episode of major depressive disorder. If grief and depression do co-occur, the depressive symptoms and functional impairment tend to be more severe with a poorer prognosis compared with bereavement uncomplicated by major depressive disorder. Bereavement-related depression tends to occur in persons with other vulnerabilities to or a past history of depressive disorders. In these cases recovery may require antidepressant treatment. ${ }^{6}$

DSM-5 lists nine symptoms of major depressive disorder:

"1. Depressed mood most of the day, nearly every day, as indicated by either subjective report (e.g., feels sad, empty, hopeless) or observation made by others (e.g., appears tearful). [...] 2. Markedly diminished interest or pleasure in all, or almost all, activities most of the day, nearly every day (as indicated by either subjective account or observation). 3. Significant weight loss when not dieting or weight gain (e.g., a change of more than $5 \%$ of body weight in a month), or decrease or increase in appetite nearly every day. 4. Insomnia or hypersomnia nearly every day. [...] 5. Psychomotor agitation or retardation nearly every day (observable by others, not merely subjective feelings of restlessness or being slowed down). 6. Fatigue or loss of energy nearly every day. 7. Feelings of worthlessness or excessive or inappropriate guilt (which may be delusional) nearly every day (not merely self-reproach or guilt about being sick). 8. Diminished ability to think or concentrate, or indecisiveness, nearly every day (either by subjective account or as observed by others). 9. Recurrent thoughts of death (not just fear of dying), recurrent suicidal ideation without a specific plan, or a suicide attempt or a specific plan for committing suicide. « ${ }^{7}$

The diagnosis of major depressive disorder requires that five or more of the symptoms listed above be present during the same 2-week period and represent »a change from previous functioning: at least one of the symptoms is either (1) depressed mood or (2) loss of interest or pleasure «. ${ }^{8}$

When searching for the appropriate spiritual help for a person showing symptoms of depression it is useful to be aware of different risk factors: ${ }^{9} 1$ ) The

\footnotetext{
${ }_{5}$ American Psychiatric Association, Diagnostic and Statistical Manual of Mental Disorders DSM-5, $5^{\text {th }}$ ed., New School Library, American Psychiatric Publishing, Washington, DC, London, England 2013, 155.

${ }^{6}$ Cf. ibid.

7 Ibid., 160-161.

${ }^{8}$ Ibid., 161.

${ }^{9}$ Cf. Ibid., 155-188.
} 
first is genetics. In this context, a person has a higher probability of developing a depressive disorder due to a genetic predisposition as a history of depression in a first-degree relative-parent, sibling, grandparent-increases an individual's risk of developing depression. 2) The second risk factor is biochemical. A high level of stress can lead to a chemical imbalance and reduce the performance and efficiency of certain brain activities resulting in mood fluctuations.

3) The third risk factor is physiological. This includes coexistent physical illness, particularly terminal illness, post-cardiac arrest, head injury, diabetes, stroke. The biological risk for depression is also increased in the setting of alcohol and drug abuse. Vitamin and iron deficiency as well as thyroid disease can also cause symptoms resembling a depressive disorder. 4) A fourth risk-factor is related to anguish. Persons suffering from a high level of anguish are even more strained when they are under stress. They are proven to be more susceptible to depressive disorder. These four risk-factors for developing a depressive disorder are closely related to the body and its physiology. The persons with such risk-factors can find help in medication, health care, appropriate diet and movement as well as in similar fields.

5) The fifth risk-factor is psychological. Psychological theories of depression are mostly based on the presupposition that a traumatic event or, even more often, a chain of traumatic events, in early childhood or adulthood as well as a disordered, chaotic, and violent environment can cause a depressive disorder at a later stage in the person's life. ${ }^{10} 6$ ) The sixth risk-factor is related to powerlessness, especially to self-pity and self-accusation. 7) The seventh risk-factor is related to the person's social milieu. Too many stressful life-events can predispose to depression. These events may include job loss, bankruptcy, the loss of a beloved person, unfavorable social circumstances (unemployment, poverty ${ }^{11}$ ), family discord, and a lack of social support. Factors are usually intertwined and closely tied due to difficult life circumstances or there is a specific trigger that pushes person into depression. 8) Gender is usually specified among the last

\footnotetext{
${ }^{10}$ Cf. Sara JEREBIC, Drago JEREBIC, Odvisnost kot oblika malikovanja [Addiction as a Form of Idolatry], Bogoslovni vestnik, 71 (2011) 2, 279-292; Sara JEREBIC, Drago JEREBIC, Consequences of childhood sexual abuse for intimate couple relationship according to relational marital therapy, The person and the challenges, 8 (2018) 2, 133-146, doi: http://dx.doi.org/10.15633/ pch.2566.

${ }^{11}$ The seventh risk-factor, social milieu, is of particular importance in the Bible. When abused, poverty is depicted as its main negative consequence, therefore, special attention and narrative context is given to this topic (e.g. the tenth commandment in the decalogue); Cf. Samo SKRALOVNIK, The meaning and interpretation of desire in the Tenth Commandment (Exod 20,17): the semantic study of the hmd word field, Biblische Notizen, 171 (2016) 13-25; Samo SKRALOVNIK, The Tenth commandment (Deut 5:21): two different verbs, the same desire, Bogoslovni vestnik, 76 (2016) 1, 89-99. But also an abundance of goods can lead to a state of frustration or even depression (cf. Mateja PEVEC ROZMAN, Pomen in vloga religije v sodobni postmoderni družbi in iskanje bistva religioznega fenomena [The Meaning and Role of Religion in Postmodern Society and the Question of the Essence of the Religious Phenomenon], Bogoslovni vestnik, 77 (2017) 2, 289-301, 291).
} 
factors that contribute to the risk of developing a depressive disorder. Twice as many women as men suffer from depression. ${ }^{12}$ The latter four backgrounds of developing a depressive disorder are related to the field of mental health and interpersonal relationships. These are called the psychosocial factors. The persons from such backgrounds primarily find help in psychology, psychotherapy, social work for individuals or families, marital and family therapy.

It would be fair to augment this list with factors that are primarily spiritual in nature, such as the loss of meaning in life, the loss of purpose in and values life, being trapped in unforgiveness, hatred, and vengeance. Persons with such backgrounds are in particular need of spiritual help.

However, it is important to consider that these various backgrounds interlock and are not one-way related in terms of cause and effect, their relationship is instead circular. For example, a constantly high level of chronic anxiety can lead to depression, whereas the cause of the anxiety may lie in troubled relationships making it difficult to distinguish between the physical and relational influences.

The backgrounds that sustain depression include those listed above as well as the inconveniences resulting from the depression itself, in part because the person has difficulties with solving problems.

Depression causes immeasurable pain in those who suffer from it and in those persons closest to them. It ruins the lives of persons who suffer from it and the lives of their family members. Many persons suffering from depressive disorder do not receive any treatment and do not believe that their illness can be cured. Depression is different from grief which is the expected response to a loss. The process of grieving helps a person to accept that which has happened, to detach from what he lost, and to find strength to continue his life. When a person is grieving, the self-respect he carries within himself remains untouched. In the depths of himself and in God he believes in, he can find hope to proceed with his life. Apart from the feeling of sadness, depression causes despair and a lack of hope and meaning in life. ${ }^{13}$

There are numerous descriptions of depression related to spiritual desolation in the Bible. It can be recognized in King David's descriptions of his feelings after the sin he did not confess. ${ }^{14}$ The losses Job suffered lead him to curse the day on which he was born. ${ }^{15}$ Elijah was depressed because of his relationship to the Israeli leaders that he wanted to die. ${ }^{16}$ Depression may occur in the

\footnotetext{
${ }^{12} \mathrm{Cf}$. Gwendoline SMITH, Premagajmo depresijo! Kako pomagati ljubljeni osebi v depresiji [Let's Overcome Depression! How to Help a Loved One in Depression], Izola, Meander, 2006, 24-27; Nuša KONEC JURIČIČ, Depresija [Depression], http://www.nijz.si/sl/depresija (01.12.2019).

${ }^{13}$ Cf. Clinton, The Quick-Reference Guide..., 73-74.

${ }^{14}$ Cf. Psalms 38 and 51, https://www.biblegateway.com/versions/New-International-VersionNIV-Bible\#booklist (16.05.2020).

${ }^{15}$ Cf. Job 3:1, https://www.biblegateway.com...

${ }^{16}$ Cf. $1^{\text {th }}$ Kings 19:3-4, Job 3:1, https://www.biblegateway.com...
} 
life of every Christian regardless of how religious and active he is.$^{17}$ Oftentimes, depression goes hand in hand with difficult circumstances in a person's life, even in the life of a Christian. Depression does not discriminate.

\section{Spiritual Help for Persons Showing Symptoms of Depression}

Reflecting on spiritual help for persons suffering from depression or other illnesses, one needs to bear in mind that health does not simply denote the absence of illnesses or distress but also includes the person's ability to cope with the symptoms of depression. A healthy person is a person with the strength or resources to fulfill his life mission. This is why a person's health does not only include his personal and professional ability, but also his determination to withstand inevitable suffering and his compassion for the suffering of other people. ${ }^{18}$ In this context, health constitutes resilience that enables a person to live with his disabilities, injuries, and illnesses.

Biblical passages describe the state of illness and the fight against it by healing and miracles in various ways. A religious interpretation of health and illness tends to avoid the two extremes that have often arisen in history. This interpretation does not consider health to be the highest value in life, nor does it fear illness as an immediate threat to health. Similarly, the interpretation does go to the other extreme of mystifying suffering and praising illness. A believer considers both health and illness as intertwined and directing him toward his actual calling and his ultimate goal in various ways. ${ }^{19}$

When persons suffering from depression or its symptoms seek spiritual help, they should be wary of spiritualizing. Spiritualism is a belief that all hardships of a depressed person can be solved only at a spiritual level, i.e. using supernatural means, such as sacraments, prayer, asceticism, and other means. It almost entirely disregards the physical and psychological dimensions along with everything else a person needs to be able to live his life to the fullest. For this reason, it is important to be familiar with different risk factors and symptoms of depression so that one can discern when a person truly needs the help of a physician or psychiatrist when a person cannot set out on the path of

\footnotetext{
${ }^{17}$ Cf. Clinton, The Quick-Reference Guide..., 74-75.

${ }^{18} \mathrm{Cf}$. Eberhard SCHOCKENHOFF, Etika življenja: Temeljna načela in konkretna vprašanja [orig. Ethik des Lebens. Grundlagen und neue Herausforderungen], Celje, Celjska Mohorjeva družba, 2013, 278; James MENSCH, Non-Useless Suffering, Bogoslovni vestnik, 79 (2019) 2, 315-322, doi: https://doi.org/10.34291/BV2019/02/Mensch; Emmanuel FALQUE, The Original Injury or the Trauma of Love, Bogoslovni vestnik, 79 (2019) 2, 307-314, doi: https://doi. org/10.34291/BV2019/02/Falque.

${ }^{19}$ Cf. Schockenhoff, Etika življenja..., 288-289; Tanja PATE, Sistemska in duhovna perspektiva zdravja in bolezni [Systemic and Spiritual Perspective on Illness and Health), Bogoslovni vest$n i k, 76$ (2016) 2, 433-439, 435-438.
} 
healing without such help. Indeed, many persons with depression need medical help and it is reasonable to direct them to seek such help.

If a person is found to have suicidal ideations and thoughts of self-harm, other family members and, especially, a psychiatrist should be engaged without hesitation. It is in the best interest of such a person to receive multiple forms of help simultaneously, because as a physical, mental, and spiritual being he needs help at all levels that are crucial for his health as a whole. If deemed necessary, it is reasonable that a person take hospitalization or medication as prescribed in order to gain a certain amount of control over self-harm and depression. Using medications does not suggest that a person weak or lacking in faith.

It should be emphasized that - as highlighted by Mario Jurišić, a person who experienced a major depressive episode himself -

»a treatment of depression based purely on medications is insufficient in most cases. It would be imperative to include spiritual help into psychiatric practices, because the medications enable the person to achieve a biochemical balance that helps mitigate the physical causes and effects of depression, such as insomnia, relatively quickly. Without any proper psychological or spiritual therapy, these effects cannot be entirely eliminated, but are only alleviated « ${ }^{20}$

Many issues in the provision of spiritual help to depressed persons also arise because a large number of persons uses the term »depression « to denote only a momentary state of anxiety, grief due to a loss, tiredness, exhaustion, or other consequences of overwork. Similarly, some persons describe "spiritual desolation ${ }^{21}{ }^{21}$ simply as disappointment about what they have considered an ideal spiritual life. Such confusion arises because the spiritual life of a Christian has its own reality and dynamic that manifests itself and is realized through the mental abilities of the person. Thus, it is challenging to distinguish between the symptoms arising from the spiritual desolation and the symptoms

\footnotetext{
${ }^{20}$ Ivan PLATOVNJAK, Interview with Mario Jurišić (22.03.2019), Ivan Platovnjak's Personal Archive.

${ }^{21}$ Every Christian alternate between the state of comfort and desolation in his spiritual life. Nothing goes right any more. He feels confused, discouraged, doubtful, tempted (...) He loses the taste of spiritual life. God seems remote. »The soul feels lazy, lukewarm, sad, as if it were separated from its Creator and Lord. It is like a dry land where the is no water. In such moments, we feel more under the influence of the demon, but this neither signifies a state of sin nor does it mean that God has forsaken us " (Monique LORRAIN, Razločevanje. Kaj se dogaja $v$ nas? [Discernment. What's happening in us?], Ljubljana, Založba Dravlje, 2017, 28-29).

Teresa of Avila described this state as follows: »There are days when all the good things, the zeal and visions, seem to abandon me. I even lose the memory of them; no matter how hard I try; I cannot find a trace of goodness within me (...) I cannot think of any godly matter ... I lack any courage for being virtuous (...) At such times, I feel that I am of no use (...) I am sad (...) It seems that I want to dispute with all my opponents. God gives me the grace not to offend Him more than I usually do. I am not asking Him to save me from such a state, but, if this is His will, to leave me in such state forever and to hold my hand so that I may not offend Him. I seek His guidance from all of my heart and I consider it a sign of His great affection that He will not leave me in such a state forever « (Ibid., 29).
} 
stemming from depression. ${ }^{22}$ This is even more difficult when a person is suffering from both at the same time. To avoid erroneous judgment of symptoms minimum criteria for discernment between spiritual desolation and depression should be defined ${ }^{23}$ These criteria were specified by Brigitte-Violaine Aufauvre, a Freudian psychoanalyst and an expert on the rules for discernment given in the Spiritual Exercises of Ignatius Loyola. ${ }^{24}$ The following points show the similarities between a depressive mood and spiritual desolation: 1) A person complains about the past experience; he presents the current experience as emotionally dissatisfying, dull, and painful. 2) His willpower is weakened and his reasoning is flawed. 3) His entire life-dynamic is diminished and he shows no interest in the outer world.

The symptoms of spiritual desolation are as follows: 1) A person complains about his relationship with God. 2) A spiritually desolated person believes that his hardship comes, above all, from the lack of consolation. 3) A person finds his abilities hampered. 4) He considers the temptation he succumbed to as the main cause of his issues.

The symptoms of a depressive mood are as follows: 1) A person complains about the image he has of himself, either consciously or subconsciously, or about the image he believes that other hold of him, or he complains about both of these. 2) The root of the problem is not clear even to the person himself. No single attempt to describe the problem is convincing even to the person himself. 3) The abilities of a person experiencing depressive mood are hampered to a greater or lesser extent. 4) The root cause lies in his subconscious processes.

\section{Various Forms of Spiritual Help in Christian Spirituality for Persons Suffering from Depression}

In Christian spirituality, there are various forms of spiritual help that can be provided to persons suffering from depression. It is often difficult to recognize immediately whether a certain person is only showing symptoms of depression or they are already truly suffering from depression as we can see in previous chapters. In this chapter, our aim is to focus on the persons who suffer from depression and to demonstrate various forms of spiritual help. In this context,

\footnotetext{
${ }^{22}$ Properly explained in Mihaly SZENTMÁRTONI, Depresija - Klinička slika. Biblijska antropologija i kršćanska vjera Clinical picture, Biblical anthropology and Christian Faith [Depression - Clinical picture. Biblical Anthropology and Christian Faith], in Veljko ĐORĐEVIĆ, Marijana BRAŠ, Lovorka BRAJKOVIĆ (edd.), Osnove palijativne medicine. Ars medica prema kulturi zdravlja i čovječnosti [Fundamentals of paliative medicine. Ars medica towards a culture of health and humanity], Mladinska naklada, Zagreb, 2013, 76-84.

${ }^{23}$ Cf. Brigitte-Violaine AUFAUVRE, Depression and Spiritual Desolation, The Way, 42 (2003) 3, 47-56, 47.

${ }^{24}$ Cf. ibid., 51-53.
} 
the specific characteristics of an individual should be considered. Every person requires comprehensive help which is why mere spiritual help oftentimes does not suffice. If the symptoms indicating a depressive disorder are primarily physiological, medical help is clearly required. If the symptoms are cognitive as the result of difficulties with interpersonal relationships, psychotherapy is certainly required. ${ }^{25}$ It can be a great help for a depressed person to find a psychiatrist or psychotherapist with adequate spiritual understanding and skills who recognizes his faith and the development of his spiritual life as a tool for an improved and comprehensive treatment. ${ }^{26}$ Some aspects of spiritual life may certainly hinder the mental well-being of a person. The form of spiritual help needed depends on the etiological factors and state of depression the person is experiencing. Although the help of a psychiatrist or psychotherapist is required in most cases of depression, adequate spiritual help is always welcome. This was verified by many persons who received both types of help as well as by some psychiatrists and psychotherapists. The author especially recalls a statement by a female psychiatrist:

»In my work, I always find it helpful and hopeful if a person has a spiritual companion. Once this person recovers, we will part ways, whereas the spiritual companion will remain ${ }^{27}$

Overcoming depression begins with a brave recognition by the depressed person that he is unhappy with his life and needs help. ${ }^{28}$ Many factors can cause depression. The depressed person should always be encouraged to first examine the physical dimension of his symptoms. It is reasonable for the person to undergo a medical examination, seek a physician's opinion, and discuss treatment options. The person should review his schedule, daily responsibilities, and his lifestyle. The person should reflect on what changes he experienced lately. Which stress factors influenced him most? Is this state a momentary one (related to the current circumstances) or is it sustained (a part of his behavior for a longer period of time)? How did his life seem prior to depression? Only when the person, to the extent possible, finds the answers to these questions, should he be assisted to outline a plan for the future. The help offered to the person also depends on whether the person was classified as perma-

\footnotetext{
${ }^{25}$ See the first chapter.

${ }^{26}$ Various research shows that personal faith has a positive effect on health [cf. Maryam SAFARA, M.S. BHATIA, Relationship of Religious Beliefs with Anxiety and Depression, Delhi Psychiatry Journal, 11 (2008) 2, 177-179].

${ }^{27}$ Ivan PLATOVNJAK, Interview with Alenka Helena Petek (31.03.2019). Ivan Platovnjak's Personal Archive. Cf. Tomaž ERZAR, Katarina KOMPAN ERZAR, The idea of mutual affect, International Journal of Applied Psychoanalytic Studies, 3 (2006) 3, 242-254, doi: https://doi. org/10.1002/aps.108.

${ }^{28}$ Cf. Mirosław MRÓZ, Physiological and Psychological Foundation of Virtues: Thomas Aquinas and Modern Challenges of Neurobiology, Scientia et Fides, 6 (2018) 2, 115-128, doi: http:// dx.doi.org/10.12775/SetF.2018.019.
} 
nently work-disabled or if the depressive disorder appeared only »temporarily« as a single event when the person's "world collapsed.« The former depressed persons are under the influence of medications affecting their mental health which makes it more difficult to motivate them in the long-term, while others depressed persons, after conquering the worst stage, have greater willpower and ability to make a change.

The former are grateful for all genuine and honest personal contact. For instance, it means a lot to them that their spiritual companion embodies the relationship that God has with them. Demanding spiritual exercises are not suitable for them. For this reason, the spiritual companion must seriously discern what he or she is able to do and when. It can be very helpful for the companion to cooperate with the psychiatrist treating this person. These persons can also benefit from self-help groups, because such groups give them the opportunity to share their hardships with and perhaps be motivated by other members of the group. At the same time, they come to realize that they are not alone and that they are understood by a person with a similar experience.

\subsection{Care for the Body}

Because a depressed person can begin to neglect his body, the care for the body in such a state is of utmost importance. ${ }^{29}$ Thirty minutes of moderate exercise is beneficial for improving not only the physical, but also the mental and spiritual mood. The depressed person should be encouraged to make time for regular physical exercise in his schedule. He should find a form of exercises that he enjoys: e.g. walking, jogging, cycling, swimming, or weight-lifting. Exercise can become a place and time to deepen the experience of loving and free closeness to God. It can be beneficial for a depressed person to invite a friend to exercise with him or to find a personal coach. If the person is aware that someone is waiting for him, he will find it easier to exercise, even when he feels reluctant to do so. It can also be helpful for the person to make a diet plan in consultation with his physician or nutritionist. ${ }^{30}$

Healthy sleep is very important for the brain and the entire body to function properly. Deep sleep refreshes the body. According to sleep professionals, sleep employs dreams to recover the person's inner world by removing the additional information. ${ }^{31}$

A depressed person also needs rituals in his daily life. If this person start his day with a positive ritual, he will be more peaceful, content, grateful, and

\footnotetext{
${ }^{29} \mathrm{Cf}$. Jan KNAPEN et al., Exercise therapy improves both mental and physical health in patients with major depression, Disability and Rehabilitation, 37 (2015), 1490-1495.

${ }^{30}$ Cf. Clinton, The Quick-Reference Guide..., 74-77.

${ }^{31}$ Cf. Samo KUŠČER, Martin KOCJAN, Irena MADRIC, Skrbimo za svoje telo [Let's Take Care of our Body], Ljubljana, Mladinska knjiga, 2008, 110.
} 
conscious as the day begins ${ }^{32}$ For instance, morning rituals can include a short prayer of praise and commendation to God, taking the time for breakfast, consciously tasting it with all the senses, taking the opportunity to wonder about all the different tastes. Mario Jurišić emphasized

»By paying attention to all the details (taste, color, scent of the dish etc.) a person's focus is shifted from the dark thoughts to a deeper awareness of the present moment (in the sense of mindfulness) «. ${ }^{33}$

In this way, a person can slowly discover the gifts he receives, how things serve for his benefit, and how God uses this to let him know that he is precious in God's eyes, that God gladly gives Himself for this person. Rituals are the factors of restoring order that calm down the unrest. ${ }^{34}$

»To reinforce his willpower, a depressed person can try to consciously decide to go jogging every day and to consistently abide by this decision. In this way, the conscious 'acceptance of the daily routine' can become an opportunity to reinforce willpower and recognize God's work in (small) daily tasks. A person can quickly develop a fear of performing routine tasks, because he finds them monotonous and unfulfilling. When he learns to discover God in these tasks, when he starts to recognize how God wants to make a gift of Himself to this person, it becomes easier for him to accept these tasks and perform them consistently in spite of not feeling any satisfaction in completing the tasks. It is important to be aware that not a single moment (or day) is the same as any other moment, regardless of how monotonous the daily schedule may seem. In every moment, God gives the person a different perception of the present moment. This perception can bring deep joy to the person «. ${ }^{35}$

Every person, especially a depressed person, must take time to do things that help him relax. He can relax every day after finishing work, at the end of the week, and on holidays. ${ }^{36}$ Sunday can help the person to pause momentarily

${ }^{32}$ Cf. Tomaž ERZAR et al., Childhood Victimization, Recent Injustice, Anger, and Forgiveness in a Sample of Imprisoned Male Offenders, International Journal of Offender Therapy and Comparative Criminology, 63 (2019) 1, 18-31, doi: https://doi.org/10.1177/0306624X18781782.

${ }^{33}$ Platovnjak, Interview with Mario... Studies have demonstrated the benefits of mindfulness, that is being aware of the present moment: Stefan G. HOFMANN et alt. The Effect of Mindfulness-Based Therapy on Anxiety and Depression: A Meta-Analytic Review, Journal of Consulting and Clinical Psychology, 78 (2010), 2, 169-183, doi: 10.1037/a0018555; Lindsay MAXWELL and Elsie DUFF, Mindfulness: An Effective Prescription for Depression and Anxiety, The Journal for Nurse Practitioners, 12 (2016), 6, 403-409, doi: https://doi.org/10.1016/j.nurpra.2016.02.009.

${ }^{34}$ Cf. Anselm GRÜN, Mir srca: Biti v sozvočju s seboj [Peace of Heart: Being in Harmony with Ourselves], Slomškova založba, Maribor, 2009, 102-103. Significant studies indicate the importance of family rituals: Sara MALAQUIAS, Carla CRESPO and Rita FRANCISCO, How do Adolescents Benefit from Family Rituals? Links to Social Connectedness, Depression and Anxiety, Journal of Child and Family Studies, 24 (2015), 3009-3017, doi: 10.1007/s10826-0140104-4.

${ }^{35}$ Cf. Platovnjak, Interview with Mario...

${ }^{36}$ Cf. Karin FELIX, Lepota in zdravje [Beauty and health], Ljubljana, Mladinska knjiga, 1991, 74. 
and become aware of everything good that happened to him in spite of his circumstances. This will help him become more attentive to what is good and beautiful as well as to the things that are not so good and that he is lacking. The person is also invited to attend Sunday services as a form of shared offering of praise for everything he and his neighbors receive as a gift. The thanksgiving dimension of the Sunday service can be an encouragement for the person to, together with Jesus, thank the Father for everything good and beautiful he receives in spite of the difficult circumstances of his illness. The giving dimension of the services stimulates the person to accept the giving love of Jesus Christ and to unite himself with Jesus so that he himself can give this love to others and can thus become like Jesus.

\subsection{Blocking Negative Thoughts}

Most authors who discuss depression emphasize the importance of thoughts in the life of a depressed person. There is a multitude of thoughts that automatically flash through a person's mind. These thoughts are of short duration and the person is usually not aware of them. He is more aware of the responses to these thoughts. There are significantly fewer thoughts that a person is aware of and are controlled by willpower. Based on their content, the thoughts can be neutral, positive, or negative. According to the Manual for People with Depression and Their Relatives,

»the biggest problem when overcoming depression is the automatic negative thoughts that disturb the person and evoke unpleasant feelings, body sensations, and behavior that does not benefit him. Such automatic thoughts constitute the basic symptoms of depression «. ${ }^{37}$

Apart from being negative, these thoughts are repetitive in their character meaning that the same thought always returns, as if a person was trapped in a vicious circle. Such a vicious circle of negative automatic thoughts and the physical, emotional, and behavioral responses to them can continue hour after hour, or for several days. "A vicious circle is formed similar to a vortex that draws the person ever deeper into a gloomy mood «. ${ }^{38}$

The depressed person should be helped to find a way to block or, at least, divert these thoughts whenever they appear.

"Certainly, the first line of defense is blocking or rejecting any thoughts that stimulate anger, sadness, or despair. As Fr. Viljem Lovše, SJ, often says: 'Do not

\footnotetext{
${ }^{37}$ Mojca Z. DERNOVŠEK, Rok TAVČAR (edd.), Prepoznajmo in premagajmo depresijo: priročnik za osebe $z$ depresijo in njihove svojce [Recognizing and Overcoming Depression: A Manual for People with Depression and Their Relatives], Ljubljana, Inštitut za varovanje zdravja RS, 2005, 24.

${ }^{38}$ Ibid., 24.
} 
let the demon and his thoughts speak, but let Jesus speak and His word of Life that brings healing and life.' Sometimes, writing the thoughts down may help, depending on the person's preferences and abilities « ${ }^{39}$

It is highly important for the person to be aware of his body and its parts, from the feet to the vertex, along with breathing and heartbeat. This can help the person to return to the present moment, because he often dwells in the past or future. Remembering the past with the purpose of learning from it or reliving the good and beautiful memories as well as looking into the future to develop concrete plans is certainly important, as long as it does not detach the person from reality for too long. For a depressed person, this is an impossible task. If such a person wants to be successful in his work and in building relationships to himself and others, to creation and God, he needs to remain in the here and now, in the present moment..$^{40}$ This is why it can be helpful for the person to perform various exercises of mindfulness in order to become aware of the material world (e.g. food, nature, body etc.) which, as a sign of God's power of creation, bears His goodness, beauty, and reality within itself and demonstrates the purpose of everything that exists. ${ }^{41}$ It also reveals God's benevolence and His perception of man. Unquestionably, such a person must be reminded and taught gradually to recognize God's voice and be open to His teaching. ${ }^{42}$

Prayerful reflection, meditation or Ignatian contemplation is mostly not suitable for a depressed person, "at least not in the early and main stage of the illness, because it can, at worst, deteriorate the mental state of the person who is not capable of rational thinking in his current state $«{ }^{43}$ Some depressed persons feel guilty for not being able to recollect in prayer, whereas other cannot even pray one Our Father.

Such a person should be helped to shift the focus from the head to the body. If you help the person take various body positions, his inner noise can fade away. In this way, the person does not have to think or speak pious words. The person is focusing on his body posture and is thus closer to God, because $\mathrm{He}$

\footnotetext{
${ }^{39}$ Platovnjak, Interview with Mario... About the importance of removing »black thoughts « and cultivating positive, »sunny « thoughts wrights also Slovenian psychologist, anthropologist and priest Anton Trstenjak. Cf. Mateja PEVEC ROZMAN, Anton Trstenjak v neutrudni hoji za človekom [Anton Trstenjak in Tireless Search for a Human], Edinost in dialog, 74 (2019) 1, 13 27, 24, doi: https://doi.org/10.34291/Edinost/74/Pevec.

${ }^{40} \mathrm{Cf}$. IGNACIJ LOYOLSKI, Duhovne vaje [Spiritual Exercises], Ljubljana, Župnijski urad Ljubljana - Dravlje, ${ }^{3} 1991$, No. 2; Ivan PLATOVNJAK, Jože ROBLEK, Moliti s telesom, dušo in duhom: molitveni priročnik [Praying with Body, Soul and Spirit: A Prayer Manual], Ljubljana, Župnijski zavod Dravlje, 2005, 23-24.

${ }^{41}$ Cf. Ivan PLATOVNJAK, Goodness and Health: The Culture of Goodnes, Synthesis philosophica, 32 (2017) 1, 79-92, doi: https://doi.org/10.21464/sp32106.

${ }^{42}$ Cf. Matthew 6:25-34, https://www.biblegateway.com...

${ }^{43}$ Platovnjak, Interview with Mario...
} 
is present in the person in a deeper way than the person is present in himself. ${ }^{44}$ Prayer gestures and postures can awaken positive feelings in the person, such as the basic feeling of confidence that the person is in safe hands, in God's arms, precious and unique, accepted and loved by God. Certainly, daily exercises are required that help the person take various body positions gradually and let the positions teach him, happen within him. In this way, prayer using different body positions and breathing or walking can become a valuable source of healing. ${ }^{45}$

\subsection{The Power of Words}

If the depressed person is not trapped in the vicious circle of repetitive negative thoughts, it can be helpful for him to repeat one or several words from the Bible (e.g. "You are precious in my eyes«) or merely the name of God (»Father, Jesus Christ, Holy Spirit«) in rhythm with his breathing. The Word can work within the person and reveal to him God's perspective of him so that he can build trust for the future that is planned for him, because God is with him and does not condemn him, but has trust in him and a plan for his future. ${ }^{46}$ Shifting the focus to breathing and a single word can transfer the person from thinking to experiencing.

Because numerous negative thoughts pass through the mind of a depressed person, it can be helpful for him to (simply) remain silent in God's presence. ${ }^{47}$ Certainly, it must be verified beforehand whether the person's image of God, who promised to stay with mankind forever, indeed is a true image of God as revealed by Jesus Christ and the Gospels. If not, this person must be helped to recognize the true image of God, sometimes by fighting all the false images. ${ }^{48}$ Mario Jurišić also finds this crucially important:

"If my image of God is not an image of a loving and merciful God who forgives me and accepts me regardless of all my faults, weaknesses, irrational actions, and sins from the past, then this image of God should be purified and redefined in light of the Gospel. The given person should especially be asked the following: Who is God in my life? What is He like in my eyes? Does my image of Him match with what I see in Jesus Christ, with His characteristics? « ${ }^{49}$

\footnotetext{
${ }^{44}$ Cf. Grün, Mir srca..., 97.

${ }^{45}$ Cf. Platovnjak, Roblek, Moliti s telesom..., 22.

${ }^{46}$ Cf. Jeremiah 29:11, https://www.biblegateway.com; John 3:16, https://www.biblegateway.com.

${ }^{47}$ Cf. Platovnjak, Roblek, Moliti s telesom..., 129-130.

${ }^{48}$ Cf. Karl FRIELINGSDORF, Podobe o Bogu. Kako povzročijo bolezen - kako ozdravljajo [orig. Seek the Face of God: Discovering the Power of Your Images of God], Maribor, Ognjišče, Slomškova založba, 2016. Frielingsdorf discusses the various ways to build a vivid and real Gospel-based image of God.

${ }^{49}$ Platovnjak, Interview with Mario...
} 


\subsection{Spiritual Accompaniment}

In the context of spiritual accompaniment, the primary task of a spiritual companion is to accompany the person, who, in this particular case, is suffering from depression, on his way to a deeper personal and community life with God. ${ }^{50}$ When accompanying a depressed person, the primary aim of the spiritual companion is to listen to and accept the person in the spirit of God's love and respect. In this way, he or she can visibly embody God's relationship to this person. This will help the person to realize deep inside how accepted and loved he or she is by God and that he or she can bring and commend everything he experiences to Him, so that God may enter his or her situation with His power that saves, heals, and transforms. In this context, both the companion and the accompanied person can gain a deeper experience of unconditional acceptance in God's love and its unconditional giving.

As the spiritual companion is listening with deep awareness, genuine interest, empathy, respect, love, and confidence in the power of the Holy Spirit, he or she enables the depressed person to hear his inner voice and express everything that the person carries within. At the same time, this helps the person discern and find the loving and active presence of God in everything he lives, works, feels, and thinks. The person can recognize how God is waiting for him or her at a place in his or her life where he or she thought God was not or should not be present. The person can then observe and accept all this in God's way by recognizing how He wants the Holy Spirit to lead him or her in his or her life. In this way, the person can start to live, accept, love, and respect himself and others to the fullest, that is in the same way as God does. Gradually, he or she can find the purpose of his or her life and joy for himself and for others, for his or her past, present, and future.

A spiritual companion has to be aware that a person who is suffering or has suffered from depression can be in a state of spiritual desolation. Thus, the spiritual companion must possess the skills to discern the symptoms of such desolation in a spiritual conversation with this person. Even if he or she only suspects the presence of desolation while talking to a depressed person, it is very important to direct the person to seek professional help. ${ }^{51}$

A spiritual companion should make it clear to the depressed person that the depressive suffering the person describes is not of a spiritual origin. He has to pay attention not to give advice on the psychological suffering, because the cause of person's depression does not come from the spiritual life. The spiritual companion must help the person to come to a conclusion that this suffering

\footnotetext{
${ }^{50}$ Cf. Ivan PLATOVNJAK, Spiritual Fatherhood, Direction and Accompaniment: Mutually Exclusive or Supplementary Terms?, Bogoslovni vestnik, 68 (2008) 1, 27-43, 31-41.

${ }^{51}$ Cf. Joseph A. MUNITIZ, St Ignatius of Loyola and Severe depression, The way, 44 (2005) 3, $57-69,68$.
} 
does not diminish the value of his or her spiritual life. He or she should encourage the depressed person to consult a mental health care professional. The spiritual companion can help the depressed person especially by asking God to help him or her discern how this person could continue to nurture his or her spiritual life. ${ }^{52}$

It is important that the spiritual companion pays attention to the depressed person's images of God, because these can influence the person in a very negative way if they are not in accordance with the image of God as revealed by Jesus Christ. The »Rules for Discernment of Spirits « in the Spiritual Exercises of Ignatius Loyola demonstrate a useful tool for discovering the false images of God that hinder and coerce us in our life. The fundamental rule for discerning images is as follows: »The evil spirits provoke a long-term feeling of despair and inner restlessness. On the contrary, positive and healing images of God lead to inner freedom and consolation . $^{53}$ The fundamental relationship of God to every person is reflected in Jesus Christ: Protecting the dignity and freedom of an individual based on affection and love that is eternal regardless of a person's decision for God or against Him.

The background of symptoms indicating depression often includes unforgiveness in which a person is trapped for various reasons. The unforgiveness imprisons the person in his or her hurts and pain. A spiritual companion can help this person on the long and gradual way of seeking forgiveness and allowing forgiveness take place within him or her. Forgiveness is a free gift from God that enables the person to find his or her inner freedom and establish a new relationship to himself, others, and creation, a relationship that gives the life the person longs for on the inside. ${ }^{54}$

\footnotetext{
${ }^{52}$ Cf. Aufauvre, Depression and..., 54-55. For an in-depth understanding of discernment see: Pope FRANCIS, Apostolic Exhortation Gaudete et Exsultate (March 19, 2018), http:// w2.vatican.va/content/francesco/en/apost_exhortations/documents/papa-francesco_esortazione-ap_20180319_gaudete-et-exsultate.html (12.05.2020), 166-173.

${ }^{53}$ Frielingsdorf, Podobe o Bogu..., 7.

${ }^{54}$ Psychological and psychotherapeutic assistance is very helpful on the path of comprehensive forgiveness cf. Mateja CVETEK, Čustveno odpuščanje v medsebojnih odnosih [Emotional Forgiveness in Interpersonal Relationships], Bogoslovni vestnik 72 (2012) 2, 281-295; Tomaž ERZAR, Dolga pot odpuščanja - Psihološka, socialna in terapevtska spoznanja [The Long Way of Forgiveness - Psychological, Social and Therapeutic Insights], Ljubljana, Družina, 2017; Tomaž ERZAR, Trije povezovalni momenti v terapevtskem procesu odpuščanja in krščanski model odpuščanja [Three Connecting Moments in the Therapeutic Process of Forgiveness and the Christian Model of Forgiveness], Bogoslovni vestnik, 79 (2019) 1, 9-16, doi: https://doi. org/10.34291/BV2019/01/Erzar.
} 


\subsection{Help of Other People or the Community}

As a result of depression, a depressed person quickly resorts to social isolation, because this is the easiest way of coping with the illness. Thus, it is very important for this person to search for a community in which he will feel safe, loved, and accepted. This person should be helped to realize that sitting at home will only reinforce his gloomy mood. He or she should be encouraged to seek support and spend time with positive, well-motivated, and fully mature people. This is not simple because it requires the person to take a risk and personally expose himself. New relationships can be frightening; however, they represent the only viable option that enables a change of the person's mental state to take place. It can be helpful for the depressed person to participate in a parish community, a prayer or bible study group, or in a self-help group. It is also important that the person be honest with the other participants of the group and have the courage to share his attitude and thoughts with them..$^{55} \mathrm{To}$ share his feelings and experience with the others helps the person see the world from different perspectives and provides the means for mutual enrichment. ${ }^{56} \mathrm{~A}$ person becomes fully human only when he enters a genuine relationship with the others and God.$^{57}$ Certainly, a safe environment should be fostered in all such groups to prevent abuse, even at a spiritual level.

Every person, especially a person fighting depression, needs an environment in which he is accepted as he is.

»This person especially needs a community in which learning from mistakes is accepted and respected, maybe even encouraged and welcome in the sense that a person is not afraid to take on a challenge due to the fear of making a mistake or taking a wrong decision. Often, a person learns more from the mistakes he made compared to never making any mistakes and always striving for perfection. Certainly, this awareness must include the understanding that every action has its consequence. However, a person should always be aware that God's righteousness is merciful and that God always forgives. God never abandons the person or excludes him from His love no matter how grave his sin is. God always waits for him and uses forgiveness to give him the opportunity to live his dignity to its full extent when the person freely accepts this forgiveness through his repentance and denouncement of sin which represents a distrust in the fullness of life in the relationship to God, himself, others, and creation (e.g. the atonement of King David). $\aleph^{58}$

\footnotetext{
${ }^{55}$ Cf. Clinton, The Quick-Reference Guide..., 76-78.

${ }^{56} \mathrm{Cf}$. Mateja CENTA, Umetnost življenja in kognitivno-izkustveni model čustev in čustvenosti [The Art of Life and Cognitive-Experiential Model of Emotions and Emotionality], Bogoslovni vestnik, 79 (2019) 2, 425-439, 432-435, doi: https://doi.org/10.34291/BV2019/02/Centa.

${ }^{57}$ Cf. Piotr ROSZAK, Revelation and Scripture: Exploring the Scriptural Foundations of sacra doctrine in Aquinas, Angelicum, 93 (2016) 1, 191-218.

${ }^{58}$ Platovnjak, Interview with Mario...
} 


\section{Conclusion}

Depression is a serious illness of modern times which is why special attention should be paid to the believers suffering from it so that they can receive proper help. These believers should not be given a feeling that their illness was caused by their sins or the sins of others or that this illness is not serious, or that it can be cured by prayer and regular reception of sacraments. ${ }^{59}$ No illness comes as a punishment for sin.

Indeed, nothing is impossible to God. A miracle can occur any time. However, it is a "miracle itself « for a person to be helped by a physician or psychiatrist. There is nothing wrong in directing the believers suffering from depression to a health care professional so that they can begin the process of healing as soon as possible and, in addition, diminish the possibility of relapse. Medicine profession also helps people. However, this does not mean that these persons should be left alone or that, by remaining open to the Holy Spirit and fostering a deep relationship to Jesus Christ, they should not seek spiritual help. One should be aware that, through this illness, God wants to reveal Himself to them as a loving Father. ${ }^{60}$

Often, the occurrence of depression in the life of a person can be a unique and extreme situation. When experiencing depression, the person will ask himself the fundamental question of who he really is. He will also question the purpose of his life and existence. The person will review the fundamental values and goals of his life. Often, the person is required to perform a thorough life-review. Depression can be defined as a sudden stop at the crossroads of life and an invitation to go deeper when making decisions. ${ }^{61}$ Thus, for a person in such a state it is wise to pause, reflect on his life, and find the sources of strength for a fuller life. Every person has his or her own experience and perception of the illness after recovering from it. If depression occurs as a single event and is appropriately treated, it can have a significant impact in the later life of the person. This is the boundary of the psychiatric, psychotherapeutic, existential, and spiritual dimension that every person who desires to help a depressed person should bear in mind.

Some of the options for providing spiritual help were examined and some considerations on how to prevent doing more harm than good to these persons were highlighted. Certainly, not all questions of the many pastoral care workers who encounter believers suffering from depression were answered. When

\footnotetext{
${ }^{59} \mathrm{Cf}$. Aaron KHERIATY, John CIHAK, Depresija ni greh: kako vam lahko svetniki, zakramenti in psihiatri pomagajo iz primeža depresije ter znova najti srečo [orig. Catholic Guide to Depression], Ljubljana, Družina, 2016.

${ }^{60}$ Cf. John 9:3, https://www.biblegateway.com...

${ }^{61}$ Cf. Antti MATTILA, »Life at the Crossroads « - Depression: Towards a Philosophical Approach, april 2001, https://www.researchgate.net/publication/313443652_'Life_at_the_ Crossroads'_-Depression_Towards_a_Philosophical_Approach_1_Antti_Mattila (12.05.2020).
} 
in contact with a depressed person it is of utmost importance to avoid any direct interpretations and accompany the person with respect and empathy in the spirit of Jesus Christ. Much work remains to be done in this field to make it clear what type of spiritual help can truly aid the depressed persons and what type is to be avoided. ${ }^{62}$ Fostering a greater openness for cooperation between the providers of spiritual help and the psychiatrists providing medical help as well as therapists providing psychological help would bring significant benefits to this field. In this way, the criteria to determine what type of help - psychiatric, psychotherapeutic, or/and spiritual - would be the most appropriate at a certain stage and the intensity of the illness would be clarified. This interdisciplinary cooperation would constitute the best possible help for depressed persons enabling them to live a fuller personal and community life.

\section{Ivan Platovnjak* \\ Duhovna pomoć osobama koje pate od depresije \\ Sažetak}

Trenutno mnogi stručnjaci raspravljaju i ispituju utjecaj duhovnosti na zdravlje. Više se ne može tvrditi da duhovnost ima pozitivan učinak na čovjekovo zdravlje. Papa Franjo ističe da u Katoličkoj crkvi svaka osoba nalazi duhovnost koja može pružiti ozdravljenje. Fokus ovog rada ograničen je na utjecaj duhovnosti na zdravlje osoba koje pate od depresije, posebno na oblike duhovne pomoći koji se nalaze u kršćanskoj duhovnosti. Ovaj rad bit će predstavljen u tri poglavlja. Prvo se ispituju simptomi i uzroci depresije. U drugom poglavlju autor objašnjava što predstavlja duhovnu pomoć depresivnim osobama i na koje bi aspekte trebalo obratiti posebnu pažnju kako ne bi napravili više štete nego koristi. U posljednjem poglavlju opisani su različiti oblici duhovne pomoći za depresivne osobe unutar kršćanske duhovnosti.

Ključne riječi: depresija, duhovna pomoć, kršćanska duhovnost, osobe koje pate od depresije, razlučivanje, zdravlje.

\footnotetext{
${ }^{62}$ This article is limited to introducing spiritual help in the context of Christian spirituality. However, other religions can also offer spiritual help to their believers as part of their spirituality.

* Doc. dr. sc. Ivan Platovnjak, Sveučilište u Ljubljani, Teološki fakultet, Poljanska cesta 4, SI-1000 Ljubljana, Slovenija; E-mail: ivan.platovnjak@teof.uni-lj.si.
} 